\title{
INEFFICIENCY AND PATH \\ DEPENDENCY IN CANADA'S \\ SECURITIES REGULATORY SYSTEM: \\ TOWARDS A REFORM AGENDA
}

Anita Anand and Peter Klein

Version Post-print/accepted manuscript

Citation Anand, Anita and Klein, Peter, Inefficiency and Path Dependency in

(published version) Canada's Securities Regulatory System: Towards a Reform Agenda. (2005) 42 Canadian Business Law Journal 41.

Publisher's Statement This is the peer reviewed version of the following article: Anand, Anita and Klein, Peter, Inefficiency and Path Dependency in Canada's

Securities Regulatory System: Towards a Reform Agenda. (2005) 42

Canadian Business Law Journal 41.

https://doi.org/10.2139/ssrn.612681

\section{How to cite TSpace items}

Always cite the published version, so the author(s) will receive recognition through services that track citation counts, e.g. Scopus. If you need to cite the page number of the author manuscript from TSpace because you cannot access the published version, then cite the TSpace version in addition to the published version using the permanent URI (handle) found on the record page.

This article was made openly accessible by $U$ of $T$ Faculty. Please tell us how this access benefits you. Your story matters. 


\title{
INEFFICIENCY AND PATH DEPENDENCY IN CANADA'S SECURITIES REGULATORY SYSTEM: TOWARDS A REFORM AGENDA
}

\author{
By Anita Indira Anand* and Peter Charles Klein**
}

1. Introduction

In this article, we analyze the claim that Canadian capital markets are inefficient and examine reform proposals in light of this claim. To begin, we argue on the basis of empirical evidence that the Canadian securities regime is burdened by four types of cost inefficiencies: lack of harmonization, duplication, opportunity cost risk and uncertainty. We then argue that another type of efficiency -- dynamic efficiency -- is important in analyses of capital market regulation. Dynamic efficiency takes into account whether a system is able to respond and adapt to market pressures (such as changes in investor and issuer preferences) over time.

We seek an explanation for inefficiencies in the current regime. We argue that the securities regulatory system has resulted from a path dependent legal trajectory that is heavily influenced by federal-provincial tensions over securities regulation as well as the institutions responsible for dispensing regulation. Any reform proposal must either intervene in the development of this path dependent trajectory or be conceived on the basis of existing institutions. A single regulatory model is an example of such an intervention but may be less

\footnotetext{
* John M. Olin Visiting Fellow in Law and Economics, Yale Law School (2005-2006) and Associate Professor, Faculty of Law, Queen’s University. Email: aa7@post.queensu.ca.

** $\quad$ Associate Professor, Faculty of Business Administration, Simon Fraser University.

Thanks to Mary Condon, A. Douglas Harris, John Knowlton, Frank Milne, Malcolm Thorburn, Michael Trebilcock, Fred Tung and Jacob Ziegel for their useful comments and Jessica Penley and Ryan Sheahan for their excellent research assistance. This article was presented at the $34^{\text {th }}$ Annual Consumer and Commercial Law Workshop, a roundtable discussion of the Capital Markets Institute, the Queen's Law and Economics Workshop, the Council on Financial Services Issues and the Bank of Canada prior to publication. We extend our sincere appreciation to participants of those sessions for their useful comments. Research for this paper was funded in part by the Social Sciences and Humanities Research Council of Canada and the Foundation for Legal Research.
} 
practicable than a "passport" or "principal regulator" system that allows existing provincial regulatory institutions to remain in place.

After discussing the path dependent characteristics of the securities regime, we examine current reform initiatives by comparing the single regulatory model proposed by the Wise Persons' Committee (WPC) to the passport system of regulation set out in the Memorandum of Understanding (MOU) signed by provincial ministers, including the recent manifestation of the passport system in Proposed Multilateral Instrument 11-101 “Principal Regulator System". We suggest that the passport system is unlikely to be cost efficient but that it has certain merits when the path dependent nature of the Canadian regime as well as the importance of dynamic efficiency are taken into account.

The remainder of the article proceeds as follows. Part 2 considers various types of cost inefficiencies inherent in the regulatory regime and definitional problems with the term "efficiency" used in this context. It also considers merits of multiple regulators as a means to ensure the securities system remains responsive over time. Part 3 discusses reasons for the persistence of an inefficient regulatory regime by considering the concepts of path dependency and convergence. Part 4 moves to a comparison and critique of the two principal models of reform in Canada at present--the passport system and a single regulatory model--and argues that the passport model is likely more dynamically efficient though less cost efficient than a single regulatory structure.

\section{Efficiency: Types and Parameters}

Inefficiency of the current system is frequently cited as a basis for reform. In fact, 47 of the 87 submissions to the WPC that we reviewed for this article cited inefficiency or 
duplication as a reason for reform. There is a fundamental difficulty in ascertaining what is meant when one claims that the Canadian securities regime is "inefficient". Does it refer to unnecessary duplication in the current regime? Does it mean that the costs of compliance in the current regime would be less under another regime? Does it mean that the incremental costs under another regime would be less? Does it mean that costs of the current regime outweigh the benefits and that this result would not persist under an alternative system? Does it mean that the fragmentation and lack of co-ordination between regulators result in a higher cost of capital to issuers in Canadian capital markets? In short, simply stating that the Canadian securities regime is "inefficient" without more is a criticism that requires further explanation.

Economists assess efficiency by considering social surplus, which measures the net benefits of participants in a given market. An ideally competitive market will maximize social surplus, and thus be efficient, through the utility-maximizing activities of its participants. In the case of securities markets, maximizing social surplus is synonymous with reducing the cost of capital, which has both direct and indirect cost components. Many markets fail to be efficient because of imperfections such as monopolies or externalities. For securities markets, the most important difficulty is information asymmetry. The classic regulatory response to this difficulty is to mandate disclosure and registration, both of which clearly underlie our system of securities regulation.

Economists also emphasize the need for any system of regulation to be flexible as markets change over time. This is termed "dynamic efficiency" and is distinct from the concept of cost efficiency as measured at a single point in time. When debating the efficiency of the current regulatory system and the various proposals for reform, both cost efficiency 
and dynamic efficiency need to be considered. A number of different types of cost inefficiency characterize the Canadian securities regulatory system, including inefficiency arising from lack of harmonization, duplication, opportunity cost risk and uncertainty in the Canadian regime. Each will be discussed in turn before discussing the relevance of dynamic efficiency.

Lack of Harmonization. A frequently-voiced claim is that the lack of uniformity in securities legislation across the country prevents issuers from effectively completing transactions and registrants from engaging in their business at a national level. This lack of harmonization argument is an attack on the current system for its failure to exhibit both structural and substantive uniformity. "Structural uniformity" refers to the processes by which securities regulation is implemented and depends on the particular institutions that are responsible for implementing and enforcing securities regulation. "Substantive uniformity" refers to the consistency in securities regulation, as a matter of substantive law, across jurisdictions. Thus, whereas structural uniformity refers to the institutions that administer and enforce securities law, substantive uniformity refers to the elements of the law itself.

It is clear that the Canadian securities system does not exhibit structural uniformity since it consists of thirteen separate provincial and territorial regulators administering securities law in their respective jurisdictions and utilizing different processes to implement securities regulation. The lack of structural uniformity gives rise to various types of inefficiency, such as duplication, opportunity cost risk and uncertainty discussed below. The

\footnotetext{
1 See Anita Anand, “Developing Effective Regulation in an Ineffective Regulatory Regime” (2005) 20 B.F.L.R.
} 191. 
absence of structural uniformity also gives rise to the lack of substantive uniformity: if there are thirteen separate regulatory authorities, it seems impossible to achieve harmonization on the substantive law. Admittedly, there are many areas in which securities regulation is generally harmonized, such as the regulation relating to takeover bids and public offerings. But there are other areas, such as the law relating to exempt distributions, where securities regulation has not been harmonized. ${ }^{2}$ This lack of consistency makes transactions less efficient since issuers must ensure that they comply with the particular laws of each jurisdiction before undertaking their business there.

Duplication. The existence of thirteen separate regulators gives rise to another type of cost inefficiency, which is duplication. Practicing securities lawyers often ask: how can it be efficient for an issuer, or its counsel, to review and know the securities legislation of thirteen jurisdictions? For example, a national exempt market distribution would be much simpler if only one set of rules needed to be consulted. The current rules require that issuers and their counsel refer to the laws of a majority of provinces that have signed Multilateral Instrument 45-103 and Ontario's Rule 45-501 if they wish to complete such a transaction. ${ }^{3}$ Further, fees must be paid in each jurisdiction. ${ }^{4}$

$2 \quad$ Note the differences between Ontario's Rule 45-501 Exempt Distributions, online: Ontario Securities Commission $<$ http://www.osc.gov.on.ca/en/Regulation/Rulemaking/Rules/rules.html> and Multilateral Instrument 45-103 Capital Raising Exemptions, online: British Columbia Securities Commission - Securities Act $<$ http://www.qp.gov.bc.ca/statreg/reg/S/Securities/69_2002.htm>, agreed to by the other provinces.

3 It is true that the provinces have attempted recently to harmonize the exempt market rules. However, the proposed national instrument is not an improvement over the current system since it seems to be little more than a compilation of all of the differing rules from the various jurisdictions (Ontario’s rules under Rule 45-501 and the rest of the province's rules under Multilateral Instrument 45-103). Indeed, this new proposed instrument is an example of the failure of the CSA process to achieve true harmonization. See Proposed National Instrument 45-106 National and Ontario Prospectus and Registration Exemptions (2004) 27 OSCB (Supp-3) 1 (17 December 2004).

${ }_{4} \quad$ As the submission from Barclays Global Investors Canada to the WPC stated, "The current regulatory structure leads to higher direct and indirect compliance costs than would be the case with a single national securities regulator. Direct costs are increased in a variety of ways including through the requirement to pay fees in thirteen jurisdictions, file forms with thirteen regulatory authorities and to retain local counsel in thirteen jurisdictions.” See Submission of Barclays Global Investors Canada to the Wise Person's Committee, online: Wise Persons' Committee Submissions $<$ http://www.wise-averties.ca/submitted_en.asp?file=sub_bar>. 
There is little rigorous empirical evidence to support the claim that the current regime is cost inefficient because of duplication (or any other type of inefficiency). Much of the evidence that has been gleaned regarding cost inefficiency is anecdotal and is contained in practitioners' "war stories". This anecdotal evidence is useful but only in a limited way. It exemplifies costs inherent in this system but tells us nothing about the current costs relative to those under another system. This is a key problem since, pragmatically, a discussion of costs is meaningful only in relative terms especially since a standard assumption seems to be that costs will be less under an alternative system than under the current system. But is this the case?

In a 2003 report prepared for the WPC, we conducted a study of compliance costs (the "Cost Study"). ${ }^{5}$ The Cost Study attempted to address costs arising from duplication by examining incremental costs. "Incremental costs" were defined as costs incurred by an issuer or registrant that would not have arisen if the issuer or registrant needed to comply only with the securities laws of its province or territory in conducting business throughout the country. Where incremental costs were found to be material, we considered whether alternative regulatory models possess the potential to reduce those costs.

The Cost Study addressed the issue of compliance costs using three case studies in four areas: registration, public offerings, the exempt market and takeover bids. It focused on the material incremental costs incurred under the current system as compared to three alternatives: a passport system, uniform securities regulation and a single national regulator. This comparison was somewhat imprecise because details on at least two of these

$5 \quad$ Anita I. Anand and Peter C. Klein, “The Costs of Compliance in Canada’s Securities Regulatory Regime” in A. Douglas Harris, ed., Committee to Review the Structure of Securities Regulation in Canada: Research Studies (Ottawa, Wise Persons’ Committee, 2003) 517 at p. 522, online: Wise Persons’ Committee Research Studies <http://www.wiseaverties.ca/report_en.html> [Cost Study]. 
alternatives (passport system and single regulator) were not available at the time of writing the report. Results were based on interviews with, and written responses received from, market participants who participated in our study on a confidential basis. In keeping with our mandate, the study did not examine the "total cost" of each regulatory model as a whole.

One of the main conclusions of the Cost Study was that registrants are more likely to incur material incremental costs than issuers who, by and large, do not incur such costs as a result of the existence of multiple securities regulators in Canada. Registrants uniformly reported that they incur incremental pre-trading expenditure. As a result, registrants assessed the commercial opportunities in each jurisdiction before deciding to seek registration in that jurisdiction. Firms have experienced significant delays during the registration process at the level of the firm and individual employees. Further, these firms have lost clients and encountered barriers to entry due to the existence of multiple securities regulators in Canada.

Thus, in the registration area, duplication has been a major source of inefficiency (although this may change as a result of National Policy 31-201 "National Registration System"). ${ }^{6}$ In other areas also, duplication from multiple regulators increases issuers' costs of compliance. These include filing fees in connection with transactions (e.g. exempt distributions or public offerings) and fees for hiring counsel in various jurisdictions in order to ensure compliance with legal requirements in that jurisdiction before completing the distribution. In many cases, such costs arising from the existence of multiple securities regulators will not be material to issuers, as the Cost Study suggests. The level of materiality

$6 \quad$ National Instrument 31-101 and National Policy 31-201 online http://www.osc.gov.on.ca/Regulation/Rulemaking/Current/Part3/rule_20050107 31-201_national-reg-system.jsp (January 7 , 2005). The National Registration System allows an individual or firm to apply for registration in multiple jurisdictions and deal with only one regulator. 
will vary for a number of reasons, including the size of the transaction in question and the materiality threshold chosen. However, even if the cost to a particular issuer is not material, it does not mean that an alternative model (such as a single regulatory model) would not be more efficient overall as the aggregate savings to all issuers and registrants may well be material.

Opportunity Cost Risk. In the Cost Study, case study participants uniformly reported significant incremental opportunity cost risk. Opportunity cost risk refers to "the risk that business may be lost or delayed due to regulatory requirements." 7 This can have a material adverse impact on the financial performance or capital structure of the firm. We found that such risk frequently arises due to delays in transactions or the commencement of trading. ${ }^{8}$ The delays arise for various reasons, one of which is the necessity to have transactions approved by separate regulatory authorities.

For example, in the IPOs examined as part of the Cost Study, participants incurred a minimum incremental delay of five working days waiting for non-principal regulators either to affirm or opt out of the Mutual Reliance Review System (MRRS) process. Where progress towards completion of an IPO is smooth, these budgeted incremental days may not cause companies to miss market windows. However, timetables can slip for a variety of reasons, including regulatory delay in approving transactions, and therefore these incremental delays represent a real risk to companies listing their shares on an exchange for the first time. ${ }^{9}$

\footnotetext{
$7 \quad$ Ibid., at p. 528.

Ibid., at p. 521.

Thus, in addition to lack of harmonization and duplication, opportunity cost risk is a conspicuous aspect of the inefficiency in Canada's regulatory regime. Though it is less visible than the other costs, opportunity cost risk can lead to delays in executing transactions. It can have an impact on decision-making by issuers considering a business or capital market opportunity. The opportunity cost risk that the current system occasions can be significant for issuers that have previously identified a market window and wish to get to market quickly. For example, the Cost Study reported an additional instance of opportunity cost risk that crystallized, and thus adversely affected one of the case study participants.
} 
Uncertainty. The Cost Study also found that market participants were concerned with the current state of uncertainty in Canada's regulatory regime. ${ }^{10}$ Market participants complained that the high level of uncertainty regarding which, if any, alternative model would be adopted detracts from their ability to manage their businesses. This uncertainty has become increasingly pronounced in recent years with a variety of regulatory reform proposals placed on the table, such as the provincial ministers' proposal for a passport system of regulation, ${ }^{11}$ a formal proposal for a single regulator from the federally appointed Wise Persons' Committee, ${ }^{12}$ and the Canadian Securities Administrators (CSA) Uniform Securities Legislation (USL) project. ${ }^{13}$ At the same time, some may argue that British Columbia's "principles-based" approach to legislation in contradistinction to Ontario's "rules-based" approach ${ }^{14}$ adds to the uncertainty as to how the securities regulatory regime in Canada as a whole will evolve. ${ }^{15}$ Recently, the Province of Ontario established a

During the course of an IPO, an opportunity for additional growth became available to the issuer, which it pursued. The issuer was planning to execute an additional transaction but it required the approval of one of the securities commissions before doing so. The issuer ultimately abandoned the transaction largely, though not exclusively, as a result of obstacles arising from the non-principal regulator.

$10 \quad$ Cost Study, supra, footnote 5, at p. 522.

11 See Steering Committee of Ministers, Securities Regulation in Canada: An Inter-Provincial Securities Framework (Edmonton, 2003) (Chair: Greg Melchin) online: http://www.securitiescanada.org/securities_discussion_paper_english.pdf $12 \quad$ See Wise Persons' Committee, Press Release, “Wise Persons' Committee Calls for Single Securities Regulator Built on Joint Federal-Provincial Model” (17 December 2003), online: Wise Persons' Committee <http://www.wiseaverties.ca/about_press_121703_en.html>, and Wise Persons' Committee Final Report, “It’s Time” (December 2003), online: Wise Persons' Committee < http://www.wise-averties.ca/reports/WPC\%20Final.pdf > [WPC Report]

13 See Canadian Securities Administrators, Press Release, "CSA Release Proposes Uniform Securities Legislation” (16 December 2003), online: Canadian Securities Administrators <http://www.csaacvm.ca/html_CSA/news/uniform_securites_32.htm>.

$14 \quad$ See Brent W. Aitken, “A New Way to Regulate: Innovative, Low-cost, Tough but Fair" (Paper presented to the Investment Funds Institute of Canada $16^{\text {th }}$ Annual Conference, 18 September 2002), online: British Columbia Securities Commission <http://www.bcsc.bc.ca/Publications/Aitken_IFIC.pdf>. See also Bill 38, Securities Act, 5th Sess., 37th Leg. , British Columbia, 2004 (certified correct as passed third reading 11 May 2004), online: Legislative Assembly of British Columbia <http://www.legis.gov.bc.ca/37th5th/3rd_read/gov38-3.htm> [Bill 38]. (This is the so-called "BC Model," which is discussed below). On the other hand, a prime example of the rules-based approach is the Sarbanes-Oxley Act of 2002 in the U.S.

${ }_{15}$ The tension between the approach of the Ontario Securities Commission on the one hand and the British Columbia, Alberta and Quebec commissions on the other was further exacerbated when the two western regulators and Quebec's Autorité des marchés financiers (formerly the Commission des valeurs mobilières du Québec) chose not to sign on to the corporate governance proposals introduced by the CSA Proposed Multilateral Instrument 58-101 Disclosure of Corporate Governance Practices and Multilateral Policy 58-201 Effective Corporate Governance, published for comment 
Committee to "advance the design of a single regulator" which presumably will differ from the model proposed by the WPC.16 The federal government in its February 2005 budget stated (somewhat vaguely) that it sees the benefits of a single regulatory model and will work with the provinces and territories towards an "enhanced system of securities regulation". ${ }^{17}$

The institutions behind many of these proposals have separately requested comments from market participants for their views on the workability and desirability of the proposed model at hand. Given the number of proposals currently on the table and the amount of time and expense necessary for market participants to comment on each proposal, it is not surprising that some market participants have called for finality in the reform process once and for all. ${ }^{18}$ As one commentator has stated, "The diversity of views is healthy but... this conflict leads to compromise solutions, delays in finding solutions, a lack of

on January 16, 2004 in all Canadian jurisdictions (including Alberta) except British Columbia and Quebec. See Canadian Securities Administrators “Notice 58-301” (12 March 2004), online: Alberta Securities Commission $<$ http://www.albertasecurities.com/index.php?currentPage=232>. See also National Policy 58-201 "Corporate Governance Guidelines" and National Instrument 58-101 "Disclosure of Corporate Governance Practices", are initiatives of the Canadian Securities Administrators. The instrument has been made, or is expected to be made, as a rule in each of British Columbia, Alberta, Manitoba, Ontario, New Brunswick, Nova Scotia and Newfoundland and Labrador, as a Commission regulation in Saskatchewan and Nunavut, as a regulation in Quebec, as a policy in PEI and the Yukon Territory, and as a code in the Northwest Territories. The Policy has been made, or is expected to be made, as a policy in every jurisdiction in Canada. The Policy and Instrument are expected to come into force in Ontario on June 30, 2005. See OSC, "Notice National Policy 58-201 Corporate Governance Guidelines and National Instrument 58-101 Disclosure of Corporate Governance Practices, Form 58-101F1 and Form 58-101F2” (2005) 28 OSCB 3615.

$16 \quad$ See Ontario Government, News Release, “Ontario Panel to Advance Design of a Single Regulator” (18 February 2005), online: Ontario Management Board Secretariat <http://www.gov.on.ca/MBS/english/mbs/releases/general/feb1805.html>.

17 Department of Finance Canada, The Budget Plan 2005 (Federal Budget 2005) (Ottawa, Department of Finance, 2005) at p. 164-165.

18 See Cost Study, supra, footnote 5, at p. 522. The uncertainty has compounded with changes in federal and provincial elected officials. Prior to the election of Liberal Dalton McGuinty in late 2003, the Conservative provincial government in Ontario supported the provincial ministers' passport system spearheaded by the Alberta government. Once the McGuinty government was elected, this position changed and Ontario threw its support behind a single regulator model. On June 24, 2004, Ontario released a single regulator proposal. See Modernizing Securities Regulation in Canada, Discussion Draft (7 June 2004), online: Ontario Management Board Secretariat <http://www.gov.on.ca/MBS/english/mbs/releases/general/ont_proposal--Modernizing_7june04_003.pdf>. In addition, as argued below, it is doubtful whether a passport system which only some provinces and two territories have signed will be effective in reaching this finality. At the federal level, the Liberal government, and various contenders for the Liberal leadership prior to the ascension of Paul Martin to that spot, voiced their support for a single regulator. 
predictability of solutions or, on occasion, no solution. This does not inspire the confidence in the marketplace which is fundamental to sound regulation." 19 Without question, the multitude of proposals that request feedback from issuers and registrants consumes senior management time. ${ }^{20}$

Dynamic efficiency. Cost efficiency, especially viewed in terms of costs of compliance, is perhaps the standard yardstick by which the efficiency of the securities regulatory regime is measured and evaluated. However, dynamic efficiency is also important in the analysis. Dynamic efficiency seeks to ensure that a market remains efficient as it changes through time. This requires flexibility in a regulatory regime. For example, the provinces of British Columbia and Alberta were the first to enact shorter hold periods for issuers that have filed an annual information form. ${ }^{21}$ These provinces were also the first to implement the junior capital pool structure whereby companies with no assets, cash or commercial operations can list on the TSX Venture Exchange and raise a minimum amount of capital. ${ }^{22}$ These reforms illustrate the ability of regulatory systems to take into account changes in issuers' preferences as the needs of these stakeholders evolve.

A regulatory monopoly - such as the U.S. securities law regime - may be a sound choice in terms of cost efficiency, but may not be sufficiently flexible to ensure that this efficiency is maintained as markets (including issuer and investor demands) evolve. Comparing the U.S. and Canadian financial systems, Carpentier and Suret highlight several

\footnotetext{
19 Submission of Robert MacLellan to WPC, online: Wise Persons' Committee Submissions <http://www.wiseaverties.ca/submitted_en.asp?file=sub_mac $>$.

$20 \quad$ Cost Study, supra, footnote 5.

21 This is the "SHAIF" system and has been adopted across Canada in Multilateral Instrument 45-102 Resale of Securities (2004), 27 OSCB 3580.

22 See online: Toronto Stock Exchange <http:/www.tse.com/en/pdf/CPCBrochure.pdf>.
} 
related concerns with a centralized regulator. ${ }^{23}$ They assert that centralization appears to be one of the contributing factors to the recent accounting and financial scandals in the U.S. In contrast to the U.S. securities regime, regulatory competition allows market participants to choose the regulatory system that governs them. This ability to choose better aligns the incentives of participants and regulators and thus allows local and regional interests and preferences to be more easily accommodated. ${ }^{24}$

As Carpentier and Suret suggest, a centralized regulatory model as found in the U.S. may not be readily transferable to Canada. Canadian capital markets exhibit a high degree of concentration when compared to the much more fragmented U.S. securities industry (for example, in Canada, six large banks control about two-thirds of brokerage firms and their subsidiaries). This concentration increases the risk that industry will have a disproportionate influence on the regulatory process, and may lead to regulatory capture where regulatory objectives become subservient to the needs of industry participants. ${ }^{25}$ Furthermore, the U.S. system is designed for deeper capital markets populated with a greater number of large companies than are present in Canada. ${ }^{26}$

Even if a market is cost efficient, it may not be dynamically efficient. That is, at any one point in time, a cost effective equilibrium may exist but over time, this equilibrium will inevitably shift. We acknowledge that it is difficult to measure dynamic efficiency.

23 Cécile Carpentier and Jean-Marc Suret, "The Canadian and American Financial Systems: Competition and Regulation” (2003) 29:4 Canadian Public Policy 433.

24 Roberta Romano, The Advantage of Competitive Federalism for Securities Regulation (Washington DC, The AEI Press, 2002), cited in Carpentier \& Suret, ibid., at p. 437. We recognize the findings of Poonam Puri, "Local and Regional Interests in the Debate on Optimal Securities Regulatory Structure" in Harris, supra, footnote 5. Professor Puri found that "most local regulatory responsiveness is not the product of local and regional distinctiveness. As a result, the main conclusion to be drawn from the study is that existing local and regional differences can be accommodated under different regulatory models without appreciable differences in regulatory outcomes.” However, we believe that local interests are more easily accommodated under regulatory competition than a single regulatory model. This conclusion does not seem to conflict with the Puri study.

$25 \quad$ Carpentier and Suret, supra, footnote 23, at p. 432.

$26 \quad$ Carpentier and Suret, supra, footnote 23, at p. 437. 
Nevertheless, we are confident in the importance of dynamic efficiency especially in shallow capital markets and markets that exhibit high levels of concentration. From a policy perspective, a recognition of the importance of dynamic efficiency suggests a strength of the passport system that we will discuss in Part 4 below.

3. Path dependency: Why has an inefficient system remained?

In its submission to the WPC, the OSC stated that of the 103 countries represented in the International Organization of Securities Commissions, two lack a national or supranational securities regulator: Canada and Bosnia-Herzegovina. ${ }^{27}$ Indeed, BosniaHerzogovina has since reformed its fragmented securities structure. Why is it that major common law jurisdictions including Australia, the United Kingdom and the United States have a national securities regulator but Canada does not? Why hasn't Canada embarked on full-fledged reform of its securities regulatory system to the end of achieving greater efficiency?

It is worth noting that there have been several attempts at securities law reform beginning in 1964 with the Porter Report, and continuing with the 1967 CANSEC proposal, the 1979 Proposals for a Securities Market Law for Canada, and the 1994 and 1996 MOU on a national regulatory system. ${ }^{28}$ Furthermore, meaningful but limited reform has occurred over the past seven to ten years through the efforts of the CSA. ${ }^{29}$ As is well-known, the CSA is a

27 Submission of the Ontario Securities Commission to the WPC, online: Wise Persons' Committee Submissions $<$ http://www.wise-averties.ca/report_en.html>. See also WPC Report, supra, footnote 12, at p. 9.

$28 \quad$ A. Douglas Harris, "A Symposium On Canadian Securities Regulation: Harmonization Or Nationalization?: White Paper” (October 2002). See also A. Douglas Harris, "Securities Regulatory Structure in Canada: The Way Forward" (2003), 38 C.B.L.J. 57.

29 See online: Canadian Securities Administrators <http://www.csa-acvm.ca/html_CSA/about.html\#mission>. 
body that functions through meetings of regulators, communications between executive directors and staff of each of the regulators, and inter-regulatory committees formed to oversee joint initiatives. Though its structure was more formalized in 2003 and a CSA Secretariat was established in Montreal in 2004, the CSA continues to be an informal body in that membership and agreement on initiatives are not mandatory. Nevertheless, the CSA has introduced several initiatives that reduce the costs of a fragmented securities regime to market participants, including the MRRS, ${ }^{30}$ the National Registration Database, ${ }^{31}$ the System for Electronic Disclosure by Insiders, ${ }^{32}$ and the System for Electronic Document Analysis and Retrieval ${ }^{33}$ to name a few.

Arguably, the most significant CSA innovation has been the MRRS. The MRRS has allowed for a greater level of harmonization than that which existed prior to its inception in areas such as exemptive relief applications, prospectus approvals and registration applications, reinstatements and renewals. The MRRS permits one regulator to rely on the analysis and review of another regulator so that the applicant receives comments and a decision from only one regulator on behalf of all others. The applicant thus deals only with one regulator as opposed to thirteen provided that non-principal regulators do not exercise their right to opt out. ${ }^{34}$

30 See National Policy 43-201 Mutual Reliance Review System for Prospectus and Annual Information Forms, online: OSC Proposed and Final Policies <http://www.osc.gov.on.ca/en/Regulation/Rulemaking/Policies/policies.html>. 31 See Multilateral Instrument 31-102 National Registration Database. See also National Registration Database, online: National Registration Database $<$ http://www.nrd-info.ca $>$.

32 See National Instrument 55-102 System for Electronic Disclosure by Insiders (SEDI). See also SEDI, online: SEDI <http://www.sedi.ca>.

${ }_{33}$ See National Instrument 13-101 System for Electronic Data Analysis and Retrieval (SEDAR). See also SEDAR, online: SEDAR <https://www.sedar.com>.

34 Admittedly, the MRRS has drawbacks, some of which relate to costs to market participants. The MRRS does not alleviate the necessity for market participants to pay fees in each jurisdiction. It does not imply that each regulator needs to surrender its jurisdiction but is instead based on voluntary cooperation. Thus, a regulator can opt out of the system at any time and deal with the market participant directly. Because securities laws are not uniform in each jurisdiction, market participants often must obtain advice on legal requirements in each jurisdiction. See OSC, Five Year Review Committee 
Despite these developments, Canadian jurisdictions have not experienced what we may term "convergence" in securities law. Convergence is not simply harmonization of substantive law but also includes institutional developments towards a common regulatory structure, such as a national securities commission. Indeed, there are still significant differences among the provinces that illustrate that convergence at the national level has not occurred. A most recent example of these differences is the BC Model of regulation proposed by the British Columbia Securities Commission which may be implemented in that province but which other provinces do not appear inclined to adopt. ${ }^{35}$ Unlike the securities laws of other provinces, the proposed model contains broad principles instead of specific rules. It also allows $\mathrm{BC}$ issuers to distribute new securities without a prospectus ${ }^{36}$ and provides investors with a right of action for misrepresentation in continuous disclosure documents ${ }^{37}$ to name just two distinctions. It is true that BC's so-called "harmonized interface" will allow issuers to raise capital in $\mathrm{BC}$ while relying on the rules of their home province, thereby retaining the regime for issuers raising capital in other provinces as well as BC. However, if the model is implemented, the internal securities laws of that province will still differ in significant respects from securities laws in other provinces.

Final Report: Reviewing the Securities Act (Ontario), (Toronto, 2003), online: OSC Five Year Review Committee Final Report <http://www.osc.gov.on.ca/en/Summary/srac_20030529_5yr-final-report.htm> at pp. 33-34, 36.

35 The BC Model led to the introduction of Bill 38, supra, footnote 14. The Bill has had its third reading in the BC Legislature; see "New securities regulatory framework protects investors and improves BC's business climate” (5 May 2004) online: British Columbia Securities Commission <http://www.bcsc.bc.ca/news/NR04_23.asp>. See also British Columbia Securities Commission, Securities Regulation That Works The BC Model: Draft Legislation, Commentary And Guides For A New Way To Regulate (15 April 2003), online: British Columbia Securities Commission $<$ http://www.bcsc.bc.ca:8080/comdoc.nsf/allbyunid/8415fd58ec7a533488256d090054aa94?opendocument>.

${ }_{36}$ Section 18(3) of the proposed BC Securities Act (Bill 38) allows a public issuer to complete an offering if it has filed (a) all information and records referred to in sections 22 and 23, and (b) all information and records referred to in the regulations relating to those sections. Supra, footnote 14 .

See Bill 38, supra, footnote 14, s. 89. The Province of Ontario has moved to implement statutory civil liability for misrepresentations made in continuous disclosure documents but these have not yet been proclaimed in force. See "Notice Of Amendments To The Securities Act And Commodity Futures Act” (2005) 28 OSCB 267. 
Examples of an apparent trend away from convergence are not difficult to find. The BC Model is one example; the provincial ministers' MOU (embodied recently in Multilateral Instrument 11-101 discussed below) is another. The MOU is a clear statement from the signing provinces that convergence is not an objective they currently support. These examples force us to ask: why haven't Canadian provincial and territorial securities regimes converged nationally? That is, why hasn't Canada adopted a uniform structure to regulate its capital markets (what we may term "national convergence") and why hasn't it converged with securities law regimes in place in other countries (what we may term "international convergence")?

A powerful answer to these questions is that Canada is "locked in" to the current system because of historical events. The notion of being locked into a certain set of circumstances is sometimes described as "path dependency". Path dependency posits the importance of historical events in analyzing present circumstances. ${ }^{38}$ As Liebowitz and Margolis describe, "A minimal form of path dependence is present whenever there is an element of persistence or durability in a decision.... What we have today depends critically on conditions that prevailed and decisions taken at some time in the past... Path dependence ...is simply the fact of durability." 39 In other words, history makes a difference; what happened in the past impacts actions that will be taken in the future.

In the context of the Canadian securities regulatory system, "path dependency" describes the durability of the regime and the importance of history in fashioning a reform

\footnotetext{
38 See Stan J. Liebowitz and Stephen E. Margolis, “The Fable of the Keys” (1990), 33 J.L. \& Econ. 1 at pp. 2-3; Stan J. Liebowitz and Stephen E. Margolis, “Policy and Path Dependence: From QWERTY to Windows 95” (1995), 18:3 Regulation 33.

39 Stan J. Liebowitz and Stephen E. Margolis, "Path Dependence” in The New Palgrave Dictionary of Economics and the Law, vol. 3 (New York: MacMillan, 1998) 17 at p. 18.
} 
agenda. In particular, path dependency helps to explain the current structure of the regime that has resulted from the development of Canadian constitutional law and provincial-based institutions (e.g. legislatures and securities commissions) that have charge over the development of securities legislation. Together, the jurisprudence and relevant institutions stand as historical constraints on the ability to achieve an efficient securities regulatory regime in this country.

Path dependency can also refer to decisions that may have been efficient ex ante but that do not turn out to be efficient ex post. As Liebowitz and Margolis describe, the inferiority of the original decision and the consequences of that decision are unknowable at the time the decision is made. ${ }^{40}$ At a later stage, it becomes clear that an alternative decision or path would have been more efficient. As they state, "there is a dependence on past conditions that leads to outcomes that are regrettable and costly to change." 41 Now even this form of path dependency can be employed to describe the Canadian securities regulatory system. At the time of structuring the regime, it may have been efficient for the provinces to retain control over the regulation of their local markets; securities transactions such as public offerings or private placements were likely confined to regions in which the issuer was based. However, as securities transactions have become national and even international in scope with investors spread across jurisdictions, this structure has become inefficient and certainly costly to change. ${ }^{42}$

\footnotetext{
$40 \quad$ Liebowitz and Margolis, supra note 38 at p. 18.

41 Ibid.

42 We recognize another strand of the path dependency literature which asserts that path dependence leads to inefficient outcomes. The central claim is that at the time of initial decision, if decision makers had the information that they have ex post, they would not have adopted that course of action. However, the costs of transition to move to this new state are too high and so they decide to remain with the current state of affairs. See Mark Roe, "Chaos and Evolution in Law and Economics” (1996) 109 Harv. L. Rev. 641 at p. 648, discussing “semi-strong path dependency.” If we adopted this understanding of path dependency, we would argue that given the inefficiencies discussed above, the Canadian
} 
But what are the circumstances that led to the current inefficiencies in the Canadian regulatory regime? There is a generally-held view that securities regulation is a matter of exclusive provincial legislative authority under section 92(13) of the Constitution Act, 1867 which states that provinces have constitutional authority over "property and civil rights [in the province]". 43 In a number of securities law cases, courts have relied on this provision, holding that the provincial securities legislation in question did not encroach upon the federal legislative powers. ${ }^{44}$ For example, in Mayland, ${ }^{45}$ the Privy Council shifted the division of powers between the provinces and the federal government, holding that the provincial securities legislation in question did not encroach upon the federal legislative power with respect to criminal law. Furthermore, in R. v. W. McKenzie Securities, ${ }^{46}$ the Manitoba Court of Appeal held that the provincial securities legislation did not invade the federal power to regulate trade and commerce. In Multiple Access Ltd v. McCutcheon ${ }^{47}$ the Supreme Court of Canada sought to resolve the conflict between federal corporate laws and provincial securities regulation and their overlapping insider trading provisions. The court held that both provisions were intra vires their enacting governments. The court also determined the doctrine of paramountcy did not apply here to suspend or make the provincial provisions inoperative. Thus, in Multiple Access, the provincial securities law at issue was upheld even where there was overlapping though not conflicting federal law.

securities regime would at the time of initial decision-making, have been structured differently. But remodeling it now would be too costly.

$43 \quad$ See Mayland and Mercury Oils Limited v. Lymburn and Frawley, [1932] 1 W.W.R. 578 (J.C.P.C.) [Mayland]. See also R. v. Smith, [1960] S.C.R. 776.

$44 \quad$ Mayland, ibid.

45 See ibid.

46 (1966), 55 W.W.R. 157 (Man. C.A.).

47 [1982] 2 S.C.R. 161 [Multiple Access]. 
To be clear, paramountcy is a constitutional doctrine the courts have adopted in order to address conflicts between federal and provincial legislation. In cases where there is a conflict between valid federal and provincial laws dealing with the same matter, the federal law is held to prevail, and the provincial law is rendered inoperative to the extent that it is inconsistent with the federal law. In the Multiple Access case discussed above, though the federal and provincial insider trading provisions dealt with the same matter and were virtually identical, the court still held them not to be in conflict, and so the doctrine of paramountcy did not apply. Justice Dickson stated, "In principle, there would seem to be no good reasons to speak of paramountcy and preclusion except where there is actual conflict in operation as where one enactment says 'yes' and the other says 'no'." 48

From a federal perspective, the paramountcy doctrine itself is thus quite weak. It will be a rare instance in which federal law will be deemed to be paramount. And, in the area of securities regulation, the doctrine has meant that provincial regulation has developed largely unaffected by federal laws. Furthermore, in certain areas, such as insider trading, the federal government has passed overlapping legislation which is substantially similar to existing provincial law. ${ }^{49}$ Having the same legislation at two levels of government is duplicative, seemingly unnecessary and undoubtedly inefficient.

Over time, case law and a diluted paramountcy doctrine together have led to the diminishment of federal powers over regulation of securities markets. Indeed, as Gillen points, out, the courts on balance have upheld the validity of provincial securities laws. ${ }^{50}$ On

\footnotetext{
$48 \quad$ Ibid.

49 See Criminal Code, R.S.C. 1985, c. C-46, s. 382.1 (Prohibited Insider Trading), introduced in Canada, Bill C-13 An Act to Amend the Criminal Code (Capital Markets Fraud and Evidence-Gathering), S.C. 2004, c. 3 (assented to 29 March 2004), which was made in response to the supposed crisis in investor confidence after Enron.

$50 \quad$ Mark Gillen, Securities Regulation in Canada (Toronto, Carswell, 1992), at p. 52.
} 
a strict interpretation of the law, however, it is not a foregone conclusion that securities regulation is a matter of exclusive provincial jurisdiction. In one of the first division of powers cases, Manitoba (Attorney General) v. Canada (Attorney General)51, a conflict arose whereby corporations that were incorporated under the federal residual power were prevented from issuing securities unless they obtained the prior approval of provincial authorities. The Privy Council held that the conflict was not governed by section 92 and that the provincial legislation under consideration interfered with the capacity of a Dominion incorporated company to raise capital. Furthermore, in keeping with the line of cases that gave rise to this rule, the Privy Council in Manitoba held the capacity of a Dominion company to obtain capital by the sale of its shares was essential, and therefore, the provincial legislation was ultra vires the province in so far as it applied to Dominion companies.

Thus, the Manitoba case upholds the long-standing rule that provincial legislatures are not competent to legislate so as to impair the status and essential capacities of Dominion companies in a substantial degree. It also allows the recognition that securities regulation is not necessarily in the provincial domain. 52 A solid argument can be made on the basis of existing law that the federal government does have the power to enact securities legislation. ${ }^{53}$ Bolstering this view is Dickson J.'s judgment in Multiple Access Ltd v. McCutcheon in which he was certain to retain a window for the federal government to enact legislation relating to securities and capital markets generally. ${ }^{54}$

\footnotetext{
$51 \quad$ Ibid.

52 See Manitoba (Attorney General) v. Canada (Attorney General), [1929] 1 D.L.R. 369 (J.C.P.C.) [Manitoba].

53 Constitutional Opinions of Ogilvy Renault, Torys LLP and Fasken Martineau DuMoulin LLP in Harris, supra, footnote 5, at pp. 1-44.

$54 \quad$ Multiple Access, supra, footnote 7, at p. 44. Dickson J. stated, Parliament has not yet enacted any comprehensive scheme of securities legislation. To date the Canadian experience has been that the provinces have taken control of the marketing of securities, differing in this respect from the United States where the Securities and Exchange Commission has regulated trading and primary
} 
Three constitutional opinions delivered to the WPC stated that securities regulation could fall within the federal "trade and commerce" power under section 91(2) of the Constitution Act. 55 Prior to the WPC report, academics suggested that the "peace, order and good government" clause from section 91 of the Constitution Act is a legitimate basis on which to support federal securities legislation. ${ }^{56}$ The Supreme Court of Canada itself in General Motors v. City National Leasing 57 set out five indicia for federal legislation to be valid under the general branch of the trade and commerce power. While the case did not explicitly address securities regulation, constitutional experts have expressed the opinion that a federal securities act would satisfy these five indicia. That is, the legislation must contain a general regulatory scheme; the scheme must be monitored by the regulatory oversight agency; the scheme must be concerned with trade as a whole, not with a particular industry; the provinces jointly or severally would be constitutionally incapable of enacting the legislation is question; and if one or more provinces were excluded from the legislative scheme, the exclusion would jeopardize the successful operation of the scheme elsewhere in Canada. Thus, on the basis of constitutional law alone, it is not a foregone conclusion that the provinces have exclusive jurisdiction over securities regulation. ${ }^{58}$ Nevertheless, the provinces have come to view securities regulation as solely a matter of provincial jurisdiction

distribution of securities. I should not wish by anything said in this case to affect prejudicially the constitutional right of Parliament to enact a general scheme of securities legislation pursuant to its power to make laws in relation to interprovincial and export trade and commerce. This is of particular significance considering the interprovincial and indeed international character of the securities industry.

Note also that in Global Securities Corp. v. British Columbia (Securities Commission), [2000] 1 S.C.R. 494, the Supreme Court of Canada indicated that it was prepared to recognize that there is a strong transprovincial and transnational dimension to Canadian capital markets. See Constitutional Opinion to WPC from Torys LLP, supra, footnote 533.

${ }_{55} \quad$ Constitutional Opinions of Ogilvy Renault, Torys LLP and Fasken Martineau DuMoulin LLP, supra, footnote 3.

$56 \quad$ Robert Leckey and Eric Ward, “Taking Stock: Securities Markets and Division of Powers” (1999), 22 Dal. L.J.

250. See also Constitutional Opinion of Fasken Martineau Dumoulin LLP, supra, footnote 533, at p. 34.

${ }^{57}$ [1989] 1 S.C.R. 641.

58 Indeed, the WPC Report supports this view of the federal-provincial constitutional division of powers over securities regulation. 
and, rightly or wrongly, it now seems to be generally accepted that securities regulation is exclusively within the provincial domain.

Why has a provincial-dominated securities structure persisted despite the many cost inefficiencies in the system discussed in Part II above? An understanding of constitutional law suggests that inefficiencies in the current system are due - at least in part - to the way in which legal rights have been allocated to the provincial governments through the Constitution Act and subsequent case law. The inefficiencies in Canada's securities regulatory system can in this way be said to result from path dependency in the development of securities laws and other institutions such as the constitutional division of powers. As Coffee has explained in another context, "the path dependency thesis postulates that institutions evolve along path dependent trajectories, which are heavily shaped by initial starting points and pre-existing conditions. In short, history matters, because it constrains the way in which institutions can change and efficiency does not necessarily triumph." 59

It is not only Canada's constitutional legal history that has encouraged its path dependency but also the differences among various institutions that have promulgated the law. There has been a tendency among provincial securities regulators to preserve the status quo, which includes retaining power over securities regulation in their respective jurisdictions. In addition, there are significant differences among the various securities commissions in Canada. The Autorité des marchés financiers (previously the Commission des valeurs mobilières du Québec) operates under civil law. Its opposition to the federal structure has coloured the Autorités willingness to participate in a movement to reform the

\footnotetext{
$59 \quad$ John C. Coffee, Jr., "Convergence and its Critics: what are the Preconditions to the Separation of Ownership and Control?” Columbia Law School Working paper No. 179 (12 Sept. 2000), online: SSRN

$<$ http://papers.ssrn.com/paper.taf?abstract_id=241782> at p. 4.
} 
securities regulatory structure in Canada. Similarly, the British Columbia Securities Commission has differed philosophically with the Ontario Securities Commission regarding corporate governance reform among other things. ${ }^{60}$ While British Columbia has favoured a principles-based system, Ontario has preferred a rules-based system. These philosophical differences are manifested in a number of legislative initiatives, most recently the BC model of regulation discussed above. ${ }^{61}$

If we accept that the current system is a result of historical circumstances, it is possible to view the consequences of this path dependency as well as consider possible regulatory reforms. Internationally, Canada's securities regime has not converged with the regimes in place in other countries. Proponents of convergence might argue that the efficiencies inherent in competitive markets will push Canada towards adopting the single regulatory model in place in many other jurisdictions. In other areas of law, this type of reasoning has been referred to as the "strong convergence thesis", i.e. that competition will force convergence in firms' corporate governance regimes, for example. ${ }^{62}$ Thus, the inefficiencies discussed in section 2 above are mere short-term phenomena, to be replaced with a more efficient system in the long-term.

However, we have seen that inefficiencies continue to undermine Canada's securities regulatory system despite numerous proposals to reform it. Market participants and regulators have been aware of the inefficiencies for decades but no movement towards international convergence has yet occurred. In light of this history and failure of reform

$60 \quad$ See supra, footnote 15 and accompanying text.

$61 \quad$ Bill 38, supra, footnote 14.

62 Coffee, supra, footnote 59, at p. 4 (footnotes omitted). See also Ronald Gilson, “Globalizing Corporate Governance: Convergence of Form or Function” Columbia Law School Center for Law and Economic Studies (Working Paper No. 174) (May 2000) at p. 4; Jeffrey N. Gordon, “An International Relations Perspective on the Convergence of Corporate Governance: German Shareholder Capitalism and the European Union, 1990-2000” (ECGI - Law Working Paper No. 06/2003; Harvard Law and Economics Discussion Paper No. 406) at p. 1. 
proposals, a realistic conclusion seems to be that Canada's securities regulatory system will not converge with systems in place in other countries. Rather, the inefficiencies inherent in the current system will persist, and the system will continue to evolve along its path dependent trajectory. This conclusion is borne out by the analysis of the proposed passport system of regulation in the following section, where it is argued that the passport system may reduce but does not eliminate the cost inefficiencies in the current structure.

It is worth noting that Australia recently centralized its system of securities regulation and ultimately established a single national regulator. ${ }^{63}$ Many commentators believe this change was largely stimulated by exogenous events that overcame the extent to which "lock in" was present in Australia. Specifically, a series of financial scandals and a successful constitutional challenge to the first version of a federal securities law prompted a realization among members of the public that the regime was in need of massive change. It is unclear whether the change to a federal system would have occurred without these events, and it raises the question of whether similar catalysts are needed in Canada. Perhaps a move to a passport system of regulation, though not cost-efficient, is necessary before moving to a single regulator or any other alternative model involving significant structural change. Without a catalyst, it seems as though the Canadian securities regime will continue to be locked in to its current inefficient structure.

In this section, we have attempted to account for the inefficiencies in the current securities regime. Our law and legal institutions are products of their initial historical conditions and have evolved in a path-dependent manner. The result is that the various

63 See Ralph Simmonds and Ray da Silva Rosa, "The Impact of Federalising Securities Regulation in Australia: A View from the Periphery” in Harris, supra, footnote 5, at p. 137. 
regulatory regimes in Canada have been unable to converge either at a national level or with systems in other countries. The question that arises is whether it is possible to design a reform proposal to replace the current system, thereby creating a more efficient regulatory regime. The next section examines this possibility by considering two alternative regulatory models. The extent of desired government intervention, and indeed federal government intervention, is crucial in the analysis.

\section{Designing the Reform Agenda}

Two alternatives are at the forefront of securities regulatory reform in Canada: the single regulatory model proposed by the WPC and the provincial ministers' passport system of regulation recently manifested in Multilateral Instrument 11-101. We argue that the passport system is likely a second best alternative to the single regulatory model which appears to be more cost efficient. However, we also note the greater opportunity for regulatory competition under the passport system and the corresponding likelihood that the system will be dynamically efficient. Our conclusions are, to some extent, speculative because the evidence is somewhat unclear and depends on the specifics of each proposal including the structure under which it is implemented. To begin, we outline the two regulatory models prior to embarking on a comparative discussion.

In 2003, the WPC proposed a single, federally constituted securities regulator to regulate the Canadian capital markets. Under the proposed model, a nominating committee with representatives from the provinces would select commissioners of a Canadian Securities Commission. This body would administer a single statute with a head office located in the national capital region. It would be responsible for policy development, the coordination of 
regional and district office activity, dealings with other Canadian financial sector regulators and international matters. Regional offices would be established in cities across Canada to review prospectuses and registration applications, grant exemptions, conduct compliance reviews and investigations, initiate enforcement proceedings, as well as contribute to policy development. ${ }^{64}$ Adjudication would be handled by a separate body to avoid apprehension of bias.

Also in 2003, provincial ministers issued a Discussion Paper in which they proposed a passport system of regulation. ${ }^{65}$ Under the passport system, jurisdictions enter into agreements pursuant to which one jurisdiction would recognize the decisions made by another on the basis of the rules applicable in the latter. The system is premised on the notion that there will be "host regulators" and "primary regulators." Host regulators are those in the jurisdiction where the market participant is operating or offering securities. Primary regulators are those that bear the responsibility for overseeing the market participant. Under the proposed passport system, registrants and issuers would need to meet the requirements of the primary regulator only. ${ }^{66}$ There is no requirement for harmonized legislation. ${ }^{67}$

In 2004, provincial ministers signed a Memorandum of Understanding relating to the Passport System. Notably, the Province of Ontario did not sign the document, though prior to a change in its government, it had supported the initial Discussion Paper on the passport system. ${ }^{68}$ The MOU proposes two processes that support the passport system. The first is

\footnotetext{
$64 \quad$ WPC Report, supra, footnote 12, at pp. 57-59.

65 Discussion Paper, supra, footnote 11.

$66 \quad$ Ibid., at p. 10.

$67 \quad$ Ibid., at p. 3, which states, "Legislative harmonization, at least in key areas, may be a necessary but not sufficient solution to the problems raised by stakeholders."

68 James Langton, “' 'Passport' deal to be signed: Ministers meeting Thursday in Calgary”" Investment Executive (28 September 2004) online: <http://investmentexecutive.com/client/en/News/DetailNews.asp?Id=25798\&cat=8 \&IdSection=8\&PageMem=\&nbNews=\&IdPub=>. The Province of Ontario subsequently proposed its own single
} 
mutual recognition under which participating jurisdictions would recognize that a market participant that complies with legal requirements of the primary jurisdiction is deemed to be in compliance with the legal requirements in the host jurisdiction. The second is legal delegation under which participating jurisdictions would delegate decision-making power to the primary jurisdiction. 69

The CSA recently issued for comment Proposed Multilateral Instrument 11-101 in which it crafts its "Principal Regulator System" which is in essence a manifestation of the passport system spelled out in the MOU. The Multilateral Instrument dispenses with the "host" and "primary" distinction and, following the MRRS, refers to "principal regulators" that will be responsible on behalf of other regulators to oversee and approve a transaction such an offering or distribution. Some of the items dealt with in the MOU, such as enforcement, are not covered by the Multilateral Instrument. ${ }^{70}$ Our argument here is that the Multilateral Instrument and the MOU on which it is based do not eliminate the cost inefficiencies that plague Canadian capital markets. We turn now to probe the way in which cost inefficiencies persist under these instruments before considering the political context in which the securities regulatory debate is occurring.

Lack of Harmonization. The MOU stipulates that the passport system will apply to areas that have been designated as highly harmonized, including prospectus requirements and clearance, prospectus and registration exemptions, continuous disclosure requirements and

regulatory model that did not have federal involvement which it termed a “common” regulator. See http://www.newswire.ca/en/releases/archive/February2005/18/c6139.html , supra footnote 16.

69 A Provincial/Territorial Memorandum of Understanding Regarding Securities Regulation (30 September 2004), online: Provincial-Territorial Securities Initiative <http://www.securitiescanada.org/2004_0930_mou_english.pdf > [MOU], at section 5.1.

70 .Canadian Securities Administrators, Notice and Request for Comment on Proposed Multilateral Instrument 11101 Principal Regulator System and Form 11-101F1 Principal Regulator Notice and Companion Policy 11-101CPonline http://www.albertasecurities.com/index.php?currentPage=222. 
routine discretionary exemptions. ${ }^{71}$ This suggests that other areas of securities regulation, including areas that are harmonized, such as takeover bids, are outside the passport system, at least at present. The fact that the Multilateral Instrument pertains to certain areas and not others confirms this conclusion. By contrast, the WPC model is all-inclusive since it is based on the concept of a single securities law for Canada. ${ }^{72}$

One could argue that the passport system does not detract from harmonization: It explicitly recognizes that harmonization (what we have called "substantive uniformity" above) will facilitate the operation of the system. One may further argue that, in fact, the passport system provides an incentive towards harmonization, which certainly appears to be what is occurring in the EU under the passport system. ${ }^{73}$ This conclusion would be based on the reasoning that the more securities laws across jurisdictions are harmonized on a substantive basis, the more workable the system will be. In other words, it is much easier for a jurisdiction to mutually recognize laws that are similar or identical to its own than it is to recognize laws that are significantly less developed.

However, the MOU does not require harmonization, and it is possible that other nonharmonized areas could be brought under the passport system. Indeed, Multilateral Instrument 11-101 requests comments on whether the principal regulator system should be designed to accommodate a broad range of differences in local requirements given the $\mathrm{BC}$ Model among other things. Furthermore, the model does not solve the inefficiencies induced

$71 \quad$ MOU, supra note 69., at s. 5.2 and s. 5.3 .

72 Of course, the passport system may be extended to other areas but this will depend to some extent on increased harmonization in securities regulation, the implementation of the BC Model and the success of the USL project. Ibid., at s. 7.1. The MOU states that the Ministers will work together to implement "highly harmonized securities laws" that are simplified and that build on the Uniform Securities Law (USL) project. However, Multilateral Instrument 11-101 requests comment on whether harmonization should be required under the Instrument as discussed infra. $73 \quad$ Karel Lanoo and Mattias Levin, "Securities Market Regulation in the EU: The Relation Between the Community and Member States” in Harris, supra, footnote 5, at p. 132. 
by lack of harmonization. Rather, it continues to permit differences in modes of implementation even though two or more jurisdictions may agree to implement the same law. Jurisdictions can apply the law and undertake enforcement issues (including investigations) differently even if the law is harmonized. Differing philosophies among securities regulatory authorities may exacerbate this problem. ${ }^{74}$

Because the passport system covers only limited areas of law, it is more accurately described as a "partial passport system". Many features of the present system, including the lack of substantive, and certainly structural, uniformity, will persist. Also, questions persist regarding the interaction of the passport system with the proposed BC Model of regulation. For example, if Alberta delegates certain matters to BC, does that mean it implicitly agrees with and accepts the substantive legal components of the BC Model despite the fact that they differ from the legal rules in place in Alberta? This is clearly an issue that the passport model must address as suggested in proposed Multilateral Instrument 11-101 itself.75

Duplication. The passport system does not solve the duplication problem. Rather, it retains the current structure (based on thirteen regulatory authorities) as well as the duplication that results from this structure. Registrants and issuers will continue to pay fees in thirteen jurisdictions and file forms with thirteen regulatory authorities in certain circumstances. Many of the costs inherent in the current system will remain.

The passport system is merely an extension of the existing MRRS. To be sure, under the MRRS, one regulator (a principal regulator) bears responsibility for reviewing and

\footnotetext{
$74 \quad$ See "Effective Regulation”, supra, footnote 1. See also Mary Condon, “The Use of Public Interest Enforcement Orders by Securities Regulators in Canada” in Harris, supra, footnote 5, at 411. This study found that the articulation of the public interest in making orders was fairly consistent across provinces. However, there was significant variation in emphasis across the provinces in relation to infractions pursued to an enforcement hearing.

75 Multilateral Instrument 11-101, supra footnote 70 at p. 9.
} 
commenting on an issuer's disclosure once chosen by the issuer. ${ }^{76}$ The issuer chooses the principal regulator based on the location of the issuer's head office or other reasonable connection if the head office is in a non-participating jurisdiction. ${ }^{77}$ Non-principal regulators feed comments to the issuer through the principal regulator and otherwise rely on the review and comments of the principal regulator. Non-principal regulators can opt out of the system if they wish at any time.

Under the passport system, there appear to be no opt outs permitted on a case-by-case basis as they are under the MRRS. The MOU thus appears to be stricter than the MRRS. However, the MOU makes allowance for "voluntary exit" if the participating jurisdiction provides at least six months' notice in writing to other participating jurisdictions. ${ }^{78}$ There thus seems to be an opt out under the MOU but of a different nature than is permitted under MRRS. In short, the system continues to be non-binding but is less flexible than the MRRS in this regard.

The MOU contemplates the formation of a Council of Ministers to oversee development of highly harmonized laws and the effectiveness of the passport system. ${ }^{79}$ This Council will also discuss major policy issues and provide direction to securities regulators. The Chair of the Council will rotate and costs will be shared by the participating jurisdictions. The Council will encourage coordination efforts already being undertaken by the CSA. Ministers will request that their securities regulators work together to achieve consensus on international issues so that a common view can be presented at international meetings.

National Policy 43-201, supra, footnote 30.

Ibid., s. 3.2(1)(a)-(b).

MOU, supra, footnote 69, s. 9.2.

Ibid. 
The difficulty with this aspect of the passport system is that the Council will operate alongside existing provincial commissions as well as another voluntary organization, the CSA. It adds another layer of decision-making to this system. Again, like the CSA, the Council is completely voluntary (this time with provincial ministers as opposed to provincial securities commissions). Thus, the potential to opt out is always present (as it is in the CSA and under MRRS). We must question whether the Council of Ministers will be a useful addition to the regulatory landscape given existing structures, which already have a voice in policy making, and given that commitment to the Council's initiatives is not mandatory?

The MOU has identified a key difficulty with the current system: lack of an international voice on the world stage. It is unlikely that an optional Council of Ministers that "works together to achieve consensus on international issues" will ensure that things will change under the passport system, especially since Ontario is not a signatory to the MOU. The benefits of the recommendation are not clear and do not seem to counterbalance the costs of establishing another decision-making structure.

Assuming that the passport system operates as intended, duplication will not be significantly reduced any more than it is under MRRS. The main difference is that there will no longer be a need for a signatory to confirm that it has no comments, as participating jurisdictions must still do under MRRS. Apart from this minor administrative difference, one must ask: how much of the issuer's compliance costs will be saved by dealing with the provinces that have signed the MOU and others that still operate under the MRRS? The effects of thirteen jurisdictions will likely continue to impose costs on issuers and registrants.

Opportunity Cost Risk. The one area in which inefficiencies could be reduced under the passport model is with respect to opportunity cost risk. If mutual recognition works as 
intended, the issuer deals only with one regulator and will not be subjected to delays that arise from having multiple regulators involved in the approval process. For even under MRRS, non-principal regulators still need to indicate their participation and sign off on the prospectus. This is not the case under the passport system if the host province is a signatory to the MOU. There will be no need for non-principal jurisdictions to sign off.

However, even under the current plan, issuers and registrants still have to deal with regulators that do not implement proposed Multilateral Instrument 11-101 if they want to complete a national transaction or if they want to register in all provinces. In particular, it appears that Ontario will not adopt the Multilateral Instrument. An issuer will need to deal separately with the Ontario Securities Commission if it uses a principal regulator other than the OSC. Thus, the issuer may still suffer opportunity cost risk from having to receive approval from two authorities (at least). The passport system may alleviate some of the risk but not all. If the issuer or registrant is dealing with signatory provinces only, then opportunity cost risk stands to be reduced. But if it wishes to deal with Ontario also, this risk likely remains.

Uncertainty. As noted, the passport system under the MOU and the Multilateral Instrument only deal with areas of law that are harmonized. This means that there is one system for areas of law that are not harmonized or that otherwise rest outside of the passport system and another system for prospectus offerings, exempt distributions and registration (designated areas of law that fall within the passport system). The MOU and Multilateral Instrument 11-101 undermine the achievement of both structural uniformity and substantive uniformity by creating a separate system that rests outside the current one. This increases the 
complexity of the current system as issuers may comply with the rules of the passport system in certain circumstances but must comply with the rules of the existing system in all others.

Further complicating the passport system is the issue of which jurisdictions will act as principal regulators on which issues. Multilateral Instrument 11-101 attempts to outline the workability of the system by listing which jurisdictions act as principal regulators. However, the explanation is confusing given the various exceptions to the list of principal regulators in various circumstances. ${ }^{80}$ It is likely that issuers will find the contemplated system similarly ambiguous.

In addition, although proposed Multilateral Instrument 11-101 does not address enforcement issues, the MOU stipulates that primary jurisdictions will be responsible for the enforcement of securities law. In particular, where a host jurisdiction receives a complaint, it will conduct a preliminary assessment and then refer the complaint with its findings to the primary jurisdiction for further investigation. The host securities regulator will await the outcome of the primary regulator's investigation and, if it is in the public interest to do so, will undertake its own investigation and enforcement action if appropriate. ${ }^{81}$

The specific paragraph in the MOU dealing with enforcement is vague, ending with the statement "or if the primary regulator has referred the matter back to the host securities regulator for further action." 82 Thus, the primary regulator can choose to deal with an enforcement issue through its own enforcement actions or refer the matter back to the host regulator. The difficulty with this approach from the investor's standpoint is that the matter may "fall though the cracks" without either regulator taking enforcement action even if it

\footnotetext{
80 Multilateral Instrument 11-101 supra note 70 at p. 3. Note in particular the discussion under "Purpose and Scope" and particular mention made of New Brunswick and Ontario.

$81 \quad$ MOU, supra footnote 69 at s. 5.6.

82 Ibid.
} 
would be in the public interest to do so since one regulator may wrongly rely on another regulator to take actions that the other regulator never takes. ${ }^{83}$ Alternatively, where one regulator is not satisfied with the actions of another regulator, it takes its own enforcement action. This creates more uncertainty and the possibility of uneven enforcement actions across the country.

It is doubtful whether these provisions will enhance either harmonization in rules regarding enforcement or the consistency with which enforcement actions are brought. One recalls that the WPC's list of problems with enforcement under the current system, which included: inefficient allocation of resources, coordination difficulties in multijurisdictional proceedings; and, unjustified variation in enforcement priorities including statutory protections for investors. ${ }^{84}$ Under the MOU, it appears that the passport system would continue to allow for inefficient allocation of resources since there exists the potential for proceedings to go back and forth between different regulators. Furthermore, variation in enforcement priorities may continue especially in the case of differing regulatory philosophies, as discussed above. ${ }^{85}$

Without doubt, the passport model is not as streamlined as a single regulatory structure in terms of institutions in place and processes to be followed for initiating and

$83 \quad$ Ibid. In section 5.7, the MOU specifies an exception to this process in cases where an investor makes a claim "for financial loss to a host jurisdiction's securities regulator in those jurisdictions where the securities regulator has the authority to provide such compensation.” In those cases, the host jurisdiction may undertake its own investigation and enforcement action without referring the complaint to the primary jurisdiction. This stipulation is vague also and does not differ substantially from the basic enforcement process in section 5.6. Relevant to this discussion is Hal S. Scott, "The Future Content of the U.S. Securities Laws: Internationalization of Primary Public Securities Markets” (200) 63 Law \& Contemp. Prob. 71 who raises concerns with the adequacy of enforcement under the investor choice model proposed by Stephen J. Choi and Andrew T. Guzman, "Portable Reciprocity: Rethinking the International Reach of Securities Regulation, (1998) 71 S. Cal. L. Rev. 903. While the Choi-Guzman model contemplates reciprocity between countries as opposed to provinces and territories, Scott's comment is relevant to the argument here: "The assurance of adequate administrative enforcement is close to impossible under the Choi and Guzman proposal.” (at p. 88)

$84 \quad$ WPC Report, supra, footnote 12, at p. 26.

85 See Condon, supra, footnote 744 , at p. 445 , which states "As it is currently described, it does not appear that the implementation of a passport system would change much about the way enforcement is currently organized.” 
implementing national legislative initiatives. Participating jurisdictions retain the ability to initiate and test new legal reforms, to set and collect fees and to conduct enforcement in the manner and within the particular timeframe they choose. If progress with regards to streamlining legislation is to occur with a passport system, mutual recognition needs to exist across the country and across subject areas, including in enforcement. Without doubt, a more uniform system of enforcement would need to exist. However, the current MOU does not contemplate this. Ontario is not participating and there is only mutual recognition in areas where harmonization exists already. Furthermore, the enforcement process seems convoluted and uncertain. The passport system could occasion more, rather than less, uncertainty and confusion in Canada's securities regulatory system.

On the basis of the arguments relating to cost efficiency discussed in section 2, we have contended here that the passport system contemplated in the MOU and Multilateral Instrument 11-101 is not cost efficient. Admittedly, this conclusion is to some extent uncertain since much depends on the specifics of the passport system as well as the manner in which it is implemented. For the same reasons, it is not certain whether a single regulatory model will necessarily be cost efficient, though if it exhibits structural and substantive uniformity, it will likely be more cost efficient than the passport model. We are equivocal by necessity on the issue of cost efficiency since there is ambiguity in the structure and operation of both models. We raised this issue in the Cost Study when we considered various regulatory alternatives, albeit at a very general level. We concluded in that study that 
depending on the contemplated structure, "any of the three regulatory models will reduce or eliminate material incremental costs" .86

Dynamic efficiency under the two alternative models also needs to be considered. Based on the evidence reported in Carpentier and Suret, it appears more likely that the passport system would provide a greater degree of regulatory competition, and thus flexibility over time, than a single regulatory model. In particular, regulatory competition provides an incentive for jurisdictions to respond to local and regional market concerns; in other words, the incentives of market participants and regulators are better aligned. Admittedly, the WPC proposal does allow for regional consultation and representation which may provide the input needed for a single regulator system to exhibit dynamic efficiency (i.e. to evolve in an appropriate manner over time). Further, the path dependent nature of the regulatory environment may prevent, in the current iteration of regulatory competition found in the passport model, sufficient openness among provincial regulators for the system to change in appropriate ways over time.

Regardless of the efficiency analysis, if we accept the argument about path dependency above, it is unlikely that a single regulatory model will be implemented. That is, Canada will remain "locked in" to the current securities system and will continue to develop along the path of dependence on existing jurisprudence and institutions, including the structure of the system and its attendant fragmented and unharmonized laws. Any move away from the path dependent trajectory would require a catalyst and would be

$86 \quad$ Cost Study, supra, footnote 5, at p. 522. 
unprecedented in the history of our constitutional law and the institutions that are responsible for drafting and implementing securities regulation.

\section{Conclusion}

We have argued that a single regulatory model is likely more cost efficient than a passport system, especially if it exhibits both structural and substantive uniformity. However, a single regulatory model may not provide the same degree of dynamic efficiency as the passport system. It may also be costly to implement because of the vast structural change that would be required, such as the formation of a national regulator of some sort as well as a single securities statute among other things. Arguably, the appeal of a passport system is that it is a more pragmatic solution to the current stalemate in securities regulatory reform. The proposed passport system does not require structural change or changes in substantive law to the extent required under the single regulatory model. However, as we have seen, there are costs and other problems inherent in the passport system, especially with respect to enforcement.

A broader issue is the extent to which regulatory authorities and other lawmakers should intervene to enhance the efficiency of the regulatory regime. The lesson from our analysis is that one must understand the historical, political and legal context in which the securities regulation debate is occurring before one can appreciate why the provinces support a less cost efficient regime than may be achieved under a single regulatory model. Any federal or provincial intervention must account for the fact that the primary goal for the provinces is, and has been, to maintain or expand provincial powers not to constrict them. Indeed, securities regulation is only one of many areas in which the provinces are loathe to 
cede jurisdiction (other examples include healthcare, offshore oil and gas and natural resources) and it is wholly unsurprising that most, if not all, of them oppose the WPC model.

It may be that a modified single regulatory structure, one that recognizes the provinces' desire for autonomy, power and control, is the nearest available efficient alternative. While we have not crafted our own model in its entirety, we believe that some compromise on both sides of the debate is necessary if meaningful reform is to occur. In particular, a crucial starting point will be harmonized legislation across the board (which does not bode well for the BC Model of regulation). A second component will involve federal recognition of valuable policy initiatives that emanate from regional markets. As these suggestions indicate, any reformed structure must strive to achieve both cost efficiency and dynamic efficiency as we have argued here. 